\title{
Mitogen-activated protein kinase activation and regulation of cyclooxygenase 2 expression by platelet-activating factor and hCG in human endometrial adenocarcinoma cell line HEC-1B
}

\author{
I. Munir ${ }^{1,2}$, K. Fukunaga ${ }^{1}$, K. Miyazaki ${ }^{3}$, H. Okamura ${ }^{2}$ and E. Miyamoto ${ }^{1 *}$ \\ ${ }^{1}$ Department of Pharmacology and 'Department of Obstetrics and Gynaecology, Kumamoto University School of Medicine, Kumamoto \\ 860-0811, Japan; and ${ }^{3}$ Department of Obstetrics and Gynaecology, Shimane Medical University, Izumo 693-8501, Japan
}

\begin{abstract}
The activation of mitogen-activated protein kinase (MAP kinase) and the regulation of cyclooxygenase 2 (COX-2) were investigated in the human endometrial adenocarcinoma cell line HEC-1B by treatment with platelet-activating factor (PAF) and hCG. Pretreatment of the cells with both oestradiol and medroxyprogesterone acetate was required for MAP kinase activation and COX-2 expression to respond to PAF and hCG. PAFinduced MAP kinase activation was sensitive to MAP kinase kinase (MEK) inhibitor, PD098059, and phosphatidylinositol-3-OH kinase (PI3K) inhibitor, wortmannin. In contrast, hCG-induced MAP kinase activation was sensitive to PD098059 and protein kinase A inhibitor, H-89, but not to wortmannin. PAF-induced COX-2 expression was insensitive to PD098059 but sensitive to wortmannin, whereas hCG-induced COX-2 expression was sensitive to PD098059 and H-89 but insensitive to wortmannin. 8-(4chlorophenylthio)-cAMP, a potent cAMP analogue, induced activation of MAP kinase and expression of COX-2. These results indicate that MAP kinase is activated with PAF and hCG in HEC-1B cells. In addition, COX-2 expression is stimulated through the MAP kinase activation pathway with hCG and the wortmannin sensitive pathway with PAF in HEC-1B cells. These results also imply that protein kinase A remains upstream of hCG-induced activation of MAP kinase in HEC-1B cells.
\end{abstract}

\section{Introduction}

Decidualization of the endometrium involves extensive morphological and physiological changes in the endometrial tissue in preparation for implantation of the blastocyst. There is strong evidence for an obligatory role for prostaglandins in the initiation and maintenance of the decidual cell response. The role of prostaglandins was demonstrated in experiments in which several prostaglandins, including $\mathrm{PGE}_{2}$ and $\mathrm{PGF}_{2 \alpha^{\prime}}$ induced decidualization in hormonally primed animals (Kennedy, 1985). The inflammatory response is a characteristic feature during decidualization (McRae and Heap, 1988) and prostaglandins play a role in modulating this response. There is increasing evidence that prostaglandin production is necessary for the normal intercellular homeostatic mechanism, particularly in cells related to the immune system (Kelly, 1994). $\mathrm{PGE}_{2}$ inhibits the function of many cells of the immune system (Kelly, 1994). Monocytes produce significant amounts of PGE and thus a negative feedback control may operate during inflammation to limit cell activation and cytokine secretion (Kelly, 1994).

The discovery of cyclooxygenase 2 (COX-2) contributed significantly to the current understanding of prostaglandin

${ }^{*}$ Correspondence.

Received 5 October 1998. synthesis. COX-2 is a $70 \mathrm{kDa}$ protein induced by chorionic gonadotrophin, cytokines and tumour promoters (Smith and Dewitt, 1996); COX-1 is the non-inducible counterpart. Arachidonic acid is the principal substrate of the COX protein, which is a rate-limiting enzyme in prostaglandin biosynthesis (Smith and Dewitt, 1996). Prostaglandin receptors are expressed in the peri-implantation endometrium (Yang et al., 1997) and COX-2 is expressed during implantation in the mouse endometrium (Chakraborty et al., 1996).

Platelet-activating factor (PAF), a potent lipid mediator, is produced by the embryo (Collier et al., 1988) and uterus and is thought to be an important mediator of maternal recognition of pregnancy (O'Neill et al., 1987). In humans, $\mathrm{PAF}$ is present in the luteal phase endometrium (Alecozay et al., 1989). PAF has been correlated with generation of ionositol phosphate in endometrial tissue (Battye et al., 1992), which implies it is capable of activating phospholipase C. In guinea-pigs, PAF treatment significantly increased the output of prostaglandins in the late luteal phase in vitro (Norman and Poyser, 1992), and this was dependent upon the mobilization of intracellular calcium. There is no evidence for PAF-induced COX-2 expression in endometrial cells.

hCG is a glycoprotein hormone synthesized by the placental trophoblast. Although the physiological relevance of the action of hCG in the endometrium is not well Downloaded from Bioscientifica.com at 04/26/2023 01:13:14PM 
established, there is evidence that gonadotrophins, including hCG, enhance stromal decidualization (Han et al., 1995a). hCG also upregulates COX-2 expression during differentiation of human endometrial stromal cells into decidua (Han et al., $1995 \mathrm{~b}$ ). hCG is present in plasma after initiation of implantation of the blastocyst and hCG receptors are present in endometrial cells (Reshef et al., 1990). Therefore, it is possible that hCG plays an important role in the endometrium in early pregnancy, in addition to its role in maintaining the corpus luteum steroidogenesis of the ovary.

Most of the prostaglandin in the endometrium is produced by glandular epithelial cells (Kelly, 1994). In the human endometrium, complex interactions occur within a network of epithelial, stromal, endothelial and lymphoid cells. Since uterine luminal epithelial cells appear to mediate a decidualizing signal through their basal cell surface in response to the blastocyst, it has been hypothesized that prostaglandins released by the epithelial cells may act on the underlying stromal cells. In the present study, PAF and hCG-induced COX-2 expression was examined in the HEC$1 \mathrm{~B}$ cell line to investigate the potential role of prostaglandins of epithelial origin. This cell line retains many of the characteristics of endometrial epithelial cells and is a substrain of the HEC-1A cell line. The original cell line (HEC-1A) was derived from endometrial adenocarcinoma obtained from human uterus. Oestradiol receptors are present in HEC-1B cells (Satyaswaroop et al., 1978) and exposure of the cells to 10 or $100 \mathrm{nmol}$ oestradiol $\mathrm{l}^{-1}$ for $48 \mathrm{~h}$ modulates PAF-evoked phospholipase D activity in this cell line (Ahmed et al., 1995). Progesterone receptors are also present in HEC-1 cells (Oyama and Izutsu, 1992). The presence of mRNA encoding the PAF receptor was demonstrated using $\mathrm{RT}-\mathrm{PCR}$ in the HEC-1B cell line (Ahmed et al., 1994).

In the present study, the PAF- and hCG-mediated signalling pathway of COX-2 expression was investigated using an in vitro model in which HEC-1B cells were exposed to oestradiol and medroxyprogesterone acetate. Of particular interest was the role of MAP kinase in COX-2 expression.

\section{Materials and Methods}

\section{Materials}

The following chemicals and reagents were obtained from the indicated sources: fetal bovine serum (FBS), JRH Biosciences (Lenexa, KS); $\left[\gamma^{-32} \mathrm{P}\right] \mathrm{ATP}$ and ${ }^{125} \mathrm{I}$-labelled protein A, DuPont-New England Nuclear (Wilmington, DE); PAF-16, Calbiochem (La Jolla, CA); hCG, Mochida Pharmaceutical Co. Ltd (Tokyo, Japan); oestradiol, medroxyprogesterone acetate and 8-(4-chlorophenylthio) adenosine 3',5'-cyclic monophosphate (CPT-cAMP), Sigma Chemical Co. (St Louis, $\mathrm{MO})$; minimal essential medium (MEM) and sodium pyruvate, GIBCO BRL (Gaithersburg, MD); PD098059, RBI (Natick, MA); wortmannin, Wako Pure Chemical Industries (Osaka); H-89, Seikagaku Corporation (Tokyo, Japan); anticyclooxygenase-2 antibody, anti-pan extracellular signalregulated kinase (ERK) monoclonal antibody and anti-ERK-2 monoclonal antibody, Transduction Laboratories (Lexington, KY); rabbit anti-mouse IgG1, Zymed Laboratories (South San
Francisco, CA). Myelin basic protein (MBP) was purified from bovine brain (Deibler et al., 1972).

\section{Cell culture}

HEC-1B cell line was obtained from ATCC (Bethesda, MD). Cells were cultured in MEM supplemented with $10 \%$ FBS, $1 \mathrm{mmol}$ sodium pyruvate $\mathrm{l}^{-1}$ and $60 \mathrm{mg}$ kanamycin $\mathrm{l}^{-1}$. Cell cultures were maintained in a humidified atmosphere of $5 \% \mathrm{CO}_{2}$ and $95 \%$ air at $37^{\circ} \mathrm{C}$. The medium was replaced every 3-4 days and the cells were split every 4-5 days using trypsin $(0.05 \% \mathrm{v} / \mathrm{v})$ in $\mathrm{Mg}^{2+}$ - and $\mathrm{Ca}^{2+}$-free PBS. Cells were plated in dishes of $35 \mathrm{~mm}$ diameter for the MAP kinase assay, and in dishes of $100 \mathrm{~mm}$ diameter for the immunoblot analysis, and were cultured for 3-5 days to reach around $60 \%$ confluency. Oestradiol, medroxyprogesterone acetate or both were added to the medium for 3-5 days as indicated.

\section{Assay for MAP kinase}

The cultured cells were washed once with Krebs-Ringer Hepes buffer (KRH buffer) containing $128 \mathrm{mmol} \mathrm{NaCl} \mathrm{l}^{-1}, 5$ mmol $\mathrm{KCl} \mathrm{l}^{-1}, 1 \mathrm{mmol}$ sodium phosphate $\mathrm{l}^{-1}, 1.2 \mathrm{mmol} \mathrm{MgSO}_{4}$ $\mathrm{l}^{-1}, 10 \mathrm{mmol}$ glucose $\mathrm{l}^{-1}, 2.7 \mathrm{mmol} \mathrm{CaCl}_{2} \mathrm{l}^{-1}$ and $20 \mathrm{mmol}$ Hepes $\mathrm{l}^{-1}\left(\mathrm{pH} \mathrm{7.4)}\right.$ ) and preincubated at $37^{\circ} \mathrm{C}$ for $1 \mathrm{~h}$ in the same buffer. The cells were incubated at $37^{\circ} \mathrm{C}$ for the specified time without (control) or with the specified test agents in $\mathrm{KRH}$ buffer. After incubation, the medium was removed quickly by aspiration, and the cells were frozen in liquid nitrogen and stored at $-80^{\circ} \mathrm{C}$ until the assay was performed.

The frozen cells were scraped off the dishes and solubilized in $0.15 \mathrm{ml}$ of $50 \mathrm{mmol}$ Hepes $\mathrm{l}^{-1}$ (pH 7.4), $0.1 \%(\mathrm{v} / \mathrm{v})$ Triton-

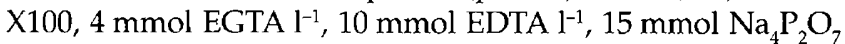
$\mathrm{l}^{-1}, 100 \mathrm{mmol} \beta$-glycerophosphate $\mathrm{l}^{-1}, 25 \mathrm{mmol} \mathrm{NaF} \mathrm{l}^{-1}$, $0.1 \mathrm{mmol}$ leupeptin $\mathrm{l}^{-1}, 75 \mu \mathrm{mol}$ pepstatin $\mathrm{A} \mathrm{l}^{-1}, 1 \mathrm{mmol}$ dithiothreitol $\mathrm{l}^{-1}, 1 \mathrm{mmol}$ ( $p$-amidinophenyl)-methanesulfonyl fluoride hydrochloride $\mathrm{l}^{-1}, 1 \mathrm{mmol} \mathrm{Na}_{3} \mathrm{VO}_{4} \mathrm{l}^{-1}$ and $100 \mathrm{nmol}$ calyculin $\mathrm{Al}^{-1}$ (solubilization solution). The procedures for the treatment of cells were carried out at $0-4^{\circ} \mathrm{C}$. After sonication (Sonifier 250; Branson), the insoluble material was removed by centrifugation at $15000 \mathrm{~g}$ for $5 \mathrm{~min}$. The extracts were treated with SDS sample buffer (Laemmli, 1970) and boiled for $3 \mathrm{~min}$. Samples containing the same amount of protein $10-15 \mu \mathrm{g}$ of protein) were assayed for MAP kinase by SDS-PAGE with MBP as a substrate as described by Kurino et al. (1995). After the gel was dried, the amount of ${ }^{32} \mathrm{P}$ incorporation into MBP at the position of MAP kinase in the gel was quantified with a Bio-imaging analyser (BA 100; Fujifilm, Tokyo).

For immunoblot analysis of MAP kinase, a similar procedure as described below for COX-2 was used, with the exception that anti-pan ERK and anti-ERK-2 antibodies (1:400 dilution) were used and the anti-mouse IgG1 antibody was omitted.

\section{Assay for COX-2 expression}

HEC-1B cells were cultured for 3-5 days in medium without hormones or with $10 \mathrm{nmol}$ oestradiol $\mathrm{l}^{-1}, 1 \mu \mathrm{mol}$ Downloaded from Bioscientifica.com at 04/26/2023 01:13:14PM 
medroxyprogesterone acetate $\mathrm{l}^{-1}$ or a combination of both hormones. Cells were incubated for $12 \mathrm{~h}$ in the absence

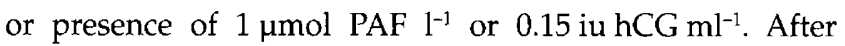
incubation, the medium was removed quickly by aspiration and the cells were frozen in liquid nitrogen and stored at $-80^{\circ} \mathrm{C}$ until assayed.

The frozen cells were scraped from the dishes and solubilized in $0.3 \mathrm{ml}$ solubilization solution, as described for the MAP kinase assay with the exception that $\mathrm{Na}_{3} \mathrm{VO}_{4}$ and calyculin A were omitted. The cells were sonicated and centrifuged as described earlier and the solubilized protein prepared in this way was designated as the Triton-X100 soluble fraction. The insoluble pellet fraction remaining after centrifugation was homogenized in $0.1 \mathrm{ml}$ solubilization solution and centrifuged, and the supernatant obtained was designated as the Triton-X100 insoluble fraction. Samples (50 $\mu \mathrm{g})$ of these proteins were then subjected to SDS-PAGE in $10 \%(\mathrm{w} / \mathrm{v})$ acrylamide and transferred electrophoretically at $75 \mathrm{~V}$ for $2 \mathrm{~h}$ to a nitrocellulose membrane. After incubating the membrane in $4.5 \%(\mathrm{w} / \mathrm{v})$ skimmed milk-Tris buffered saline (TBS; 10 mmol Tris-buffered isotonic saline $1^{-1}, \mathrm{pH} 7.4$ ) for $2 \mathrm{~h}$ to block non-specific binding sites, the membrane was incubated at $4^{\circ} \mathrm{C}$ overnight with the monoclonal anti-COX-2 antibody at dilution of $1: 125$. After washing, the membrane was incubated with the anti-mouse IgG1 antibody at a dilution of $1: 200$ for $2 \mathrm{~h}$ and finally with ${ }^{125} \mathrm{I}$-labelled protein $\mathrm{A}$ at room temperature for $1 \mathrm{~h}$. After the membrane was dried, incorporation of ${ }^{125} \mathrm{I}$ into COX-2 was quantified using a Bio-imaging analyser (BA100; Fujifilm, Tokyo).

\section{Other procedures}

Protein concentrations were determined by the method of Bradford (1976) using BSA as the standard.

\section{Statistical analyses}

Values are expressed as mean \pm SE. For multiple comparisons, the significance of the difference was calculated by one-way ANOVA plus Duncan's multiple-range test and comparisons between two experimental groups were made by the unpaired Student's $t$ test. $P$ values $<0.05$ were considered significant.

\section{Results}

\section{MAP kinase in HEC-1B cells}

MAP kinase represents a family of proteins that includes $44 \mathrm{kDa}$ ERK-1 and $42 \mathrm{kDa}$ ERK-2 in various types of cell. HEC-1B cells contained only one band of $42 \mathrm{kDa}$ by SDSPAGE, which was recognized with both the anti-pan ERK and the anti-ERK-2 antibodies (Fig. 1a). This band also migrated at the same position as ERK-2 from the positive control brain extract (Fig. 1a). Therefore, only ERK-2 of $42 \mathrm{kDa}$ was examined in the subsequent experiments.
Requirement of oestrogen and progesterone for PAF-and $h C G$-induced activation of MAP kinase and stimulation of COX-2 expression

HEC-1B cells were cultured for $3-5$ days in the absence of hormones or in the presence of $10 \mathrm{nmol}$ oestradiol $\mathrm{l}^{-1}$ and 1 $\mu \mathrm{mol}$ medroxyprogesterone acetate $\mathrm{l}^{-1}$ alone or in combination to examine the effects of oestrogen and progesterone on MAP kinase activation. After culture, cells were stimulated for 10

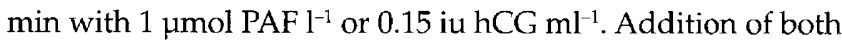
oestradiol and medroxyprogesterone acetate was required for activation of MAP kinase in HEC-1B cells with PAF and hCG (Fig. $1 b, c)$, although a small and significant increase was obtained with PAF alone in the cells pretreated with medroxyprogesterone acetate alone (Fig. 1c). In the nonstimulated cells, oestradiol or medroxyprogesterone acetate alone or in combination did not result in an increase in MAP kinase activity (data not shown).

The effects of oestrogen and progesterone on COX-2 expression were examined under the same conditions as for MAP kinase activation (Fig. 2). The Triton-X100 soluble fraction was used for all COX-2 immunoblot analyses. A small amount of COX-2 was present in the Triton-X100 insoluble fraction by centrifugation. The percentage of COX2 in the Triton-X100 insoluble fraction was about $14 \%$ of the Triton-X100 soluble fraction by treatment with hCG (data not shown). Addition of both oestradiol and medroxyprogesterone acetate was required for stimulation of COX-2 expression with PAF and $\mathrm{hCG}$, although a small increase in COX-2 expression was observed in the cells pretreated with oestradiol alone (Fig. 2b). In non-stimulated cells, oestradiol or medroxyprogesterone alone caused a small increase in COX-2 expression, but in combination the hormones caused a significant increase of $60 \%$ (data not shown).

Therefore, the subsequent experiments were performed using cells pretreated for 3-5 days with both oestradiol and medroxyprogesterone acetate.

\section{Time course and dose dependence of PAF-stimulated MAP kinase activation}

The time course of PAF-induced MAP kinase activation is shown (Fig. 3a,b). HEC-1B cells were incubated with $1 \mu \mathrm{mol}$ $\mathrm{PAF}^{-1}$ for up to $30 \mathrm{~min}$. MAP kinase activation was measured from $3 \mathrm{~min}$ to $30 \mathrm{~min}$ after stimulation with PAF (Fig. 3a). The maximum activity of MAP kinase was obtained at $10 \mathrm{~min}$ after stimulation with PAF and then decreased gradually (Fig. 3b).

HEC-1B cells were treated for $10 \mathrm{~min}$ with PAF at concentrations ranging from $10 \mathrm{nmol} \mathrm{l}^{-1}$ to $10 \mu \mathrm{mol} \mathrm{l^{-1 }}$ to determine whether the effect of PAF on MAP kinase activation was dose-dependent. Maximum MAP kinase activation was obtained with $1 \mu \mathrm{mol}$ PAF $1^{-1}$. A higher concentration of PAF $\left(10 \mu \mathrm{mol} \mathrm{l}^{-1}\right)$ inhibited MAP kinase activity (Fig. 3c).

\section{Time course and dose dependence of hCG-stimulated MAP kinase activation}

A rapid but transient activation of MAP kinase was also observed in response to hCG during incubation of the HEC-1B cells for up to $30 \mathrm{~min}$. Maximum activation of MAP kinase 
(a)

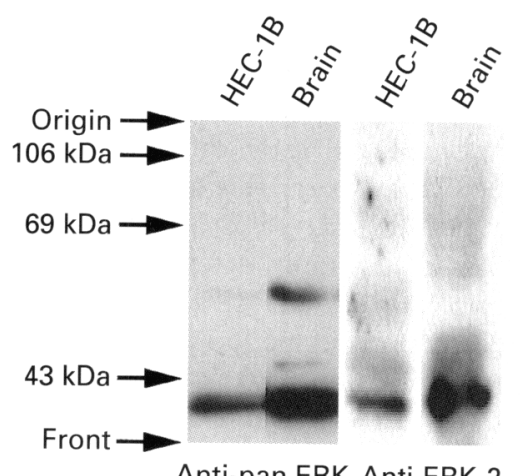

(b)

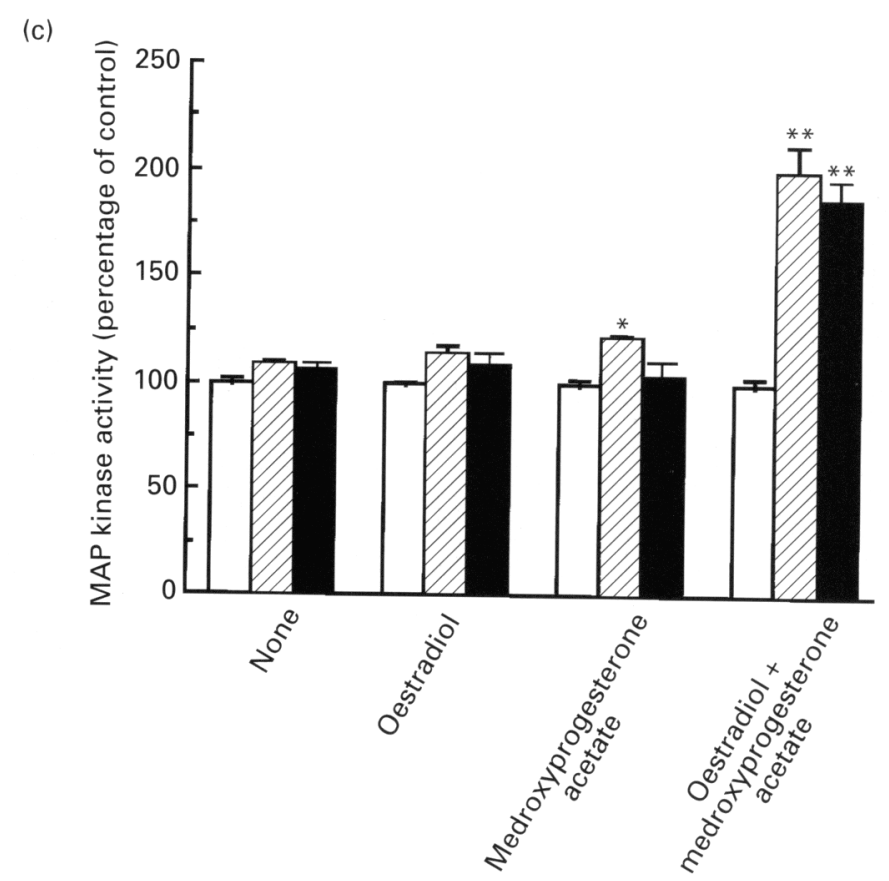

Fig. 1. Occurrence of mitogen-activated protein kinase (MAP kinase) in HEC-1B cells and the requirement of oestradiol and medroxyprogesterone acetate for the activation of MAP kinase with platelet-activating factor (PAF) and hCG. HEC-1B cells were grown for 3-5 days in culture medium without hormones or with $10 \mathrm{nmol}$ oestradiol $\mathrm{l}^{-1}$ or $1 \mu \mathrm{mol}$ medroxyprogesterone acetate $\mathrm{l}^{-1}$ alone or in combination. The cells were incubated for

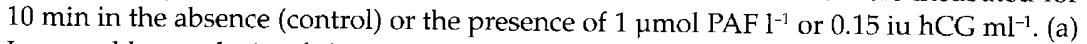
Immunoblot analysis of the cell extracts from HEC-1B cells and the homogenate of rat hippocampus (brain) with the anti-pan extracellular signal-regulated kinase (ERK) and anti-ERK-2 antibodies. (b) A representative autoradiogram of MAP kinase activation. (c) Effects of oestradiol and medroxyprogesterone acetate pretreatment on MAP kinase activation. $\square$, control; $\square$, PAF; $\mathbf{\square}$, hCG. Intensity values of control samples of cells treated with oestradiol, medroxyprogesterone acetate, or oestradiol plus medroxyprogesterone acetate relative to no hormones (none) (arbitrarily set at 100) were $105 \pm 6,107 \pm 5$, and $110 \pm 10$, respectively. The data are expressed as a percentage of the control value (Krebs-Ringer Hepes buffer only at $10 \mathrm{~min}$ ) which was designated as $100 \%$. Values are mean $\pm \operatorname{SE}(n=3) .{ }^{*} P<0.05,{ }^{* *} P<0.01$ versus control. 
(a)

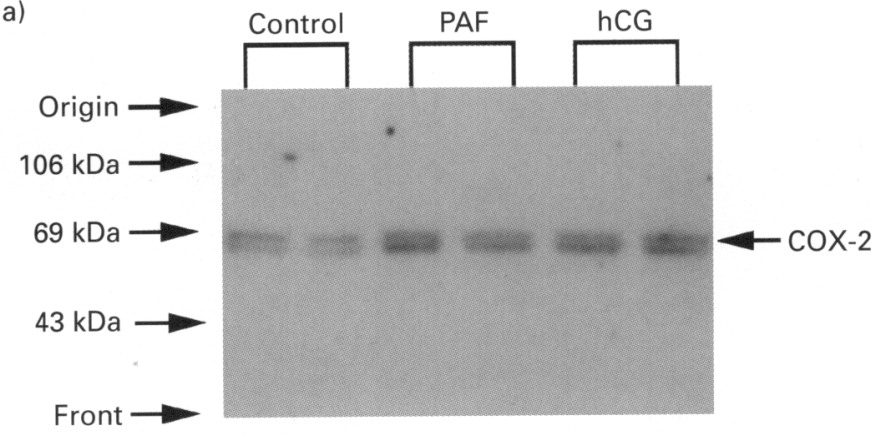

(b)

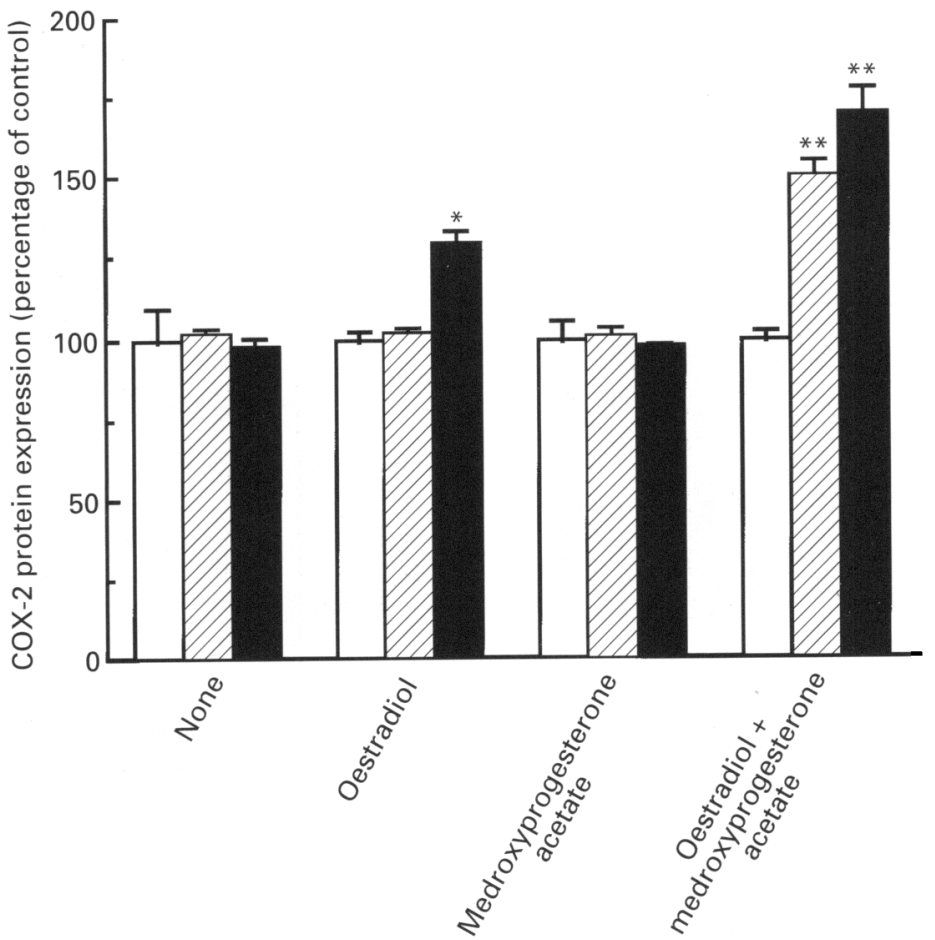

Fig. 2. Requirement of oestradiol and medroxyprogesterone acetate for stimulation of expression of cyclooxygenase 2 (COX-2) protein with platelet-activating factor (PAF) and hCG. HEC-1B cells were grown for 3-5 days in culture medium without hormones or with $10 \mathrm{nmol}$ oestradiol $\mathrm{l}^{-1}$ or $1 \mu \mathrm{mol}$ medroxyprogesterone acetate $\mathrm{l}^{-1}$ alone or in combination. Cells were incubated for $12 \mathrm{~h}$ in the absence (control) or presence of $1 \mu \mathrm{mol} \mathrm{PAF} \mathrm{^{-1 } \text { or }}$ $0.15 \mathrm{iu} \mathrm{hCG} \mathrm{ml} \mathrm{H}^{-1}$. (a) A representative autoradiogram of the COX-2 immunoblot. (b) PAF and hCG-induced COX-2 expression by pretreatment with oestradiol and medroxyprogesterone acetate. $\square$, control; $\square$, PAF; hCG. Intensity values of control samples of cells treated with oestradiol, medroxyprogesterone acetate, or oestradiol plus medroxyprogesterone acetate relative to no hormones (none) (arbitrarily set at 100 ) were $121 \pm 3.1$, $115 \pm 5$, and $160 \pm 3$, respectively. The data are expressed as a percentage of the control value which was designated as $100 \%$. Values are mean $\pm \mathrm{SE}$ $(n=3) .{ }^{*} P<0.05,{ }^{* *} P<0.01$ versus control. 
(a)

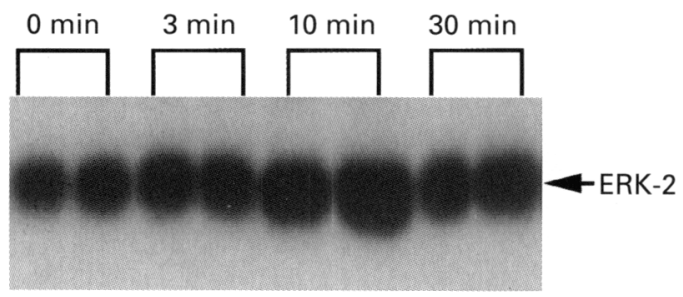

(b)

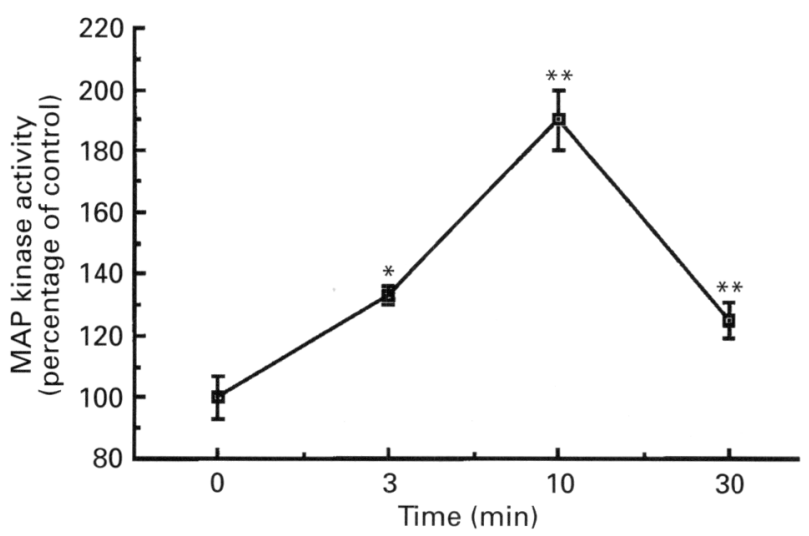

(c)

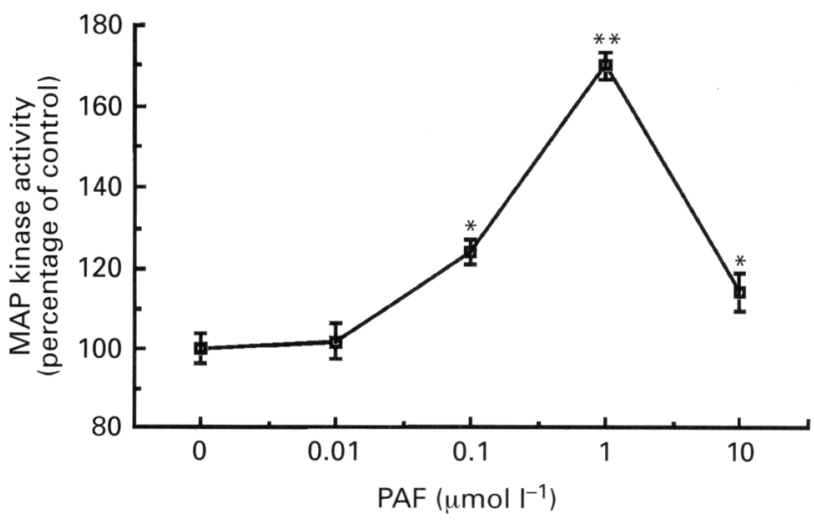

Fig. 3. Time course and concentration dependence of mitogenactivated protein kinase (MAP kinase) activation with plateletactivating factor (PAF). (a) A representative autoradiogram of the time course of MAP kinase activation induced by $1 \mu \mathrm{mol} \mathrm{PAF} \mathrm{l}^{-1}$. (b) MAP kinase activation quantified by a Bio-imaging analyser. Values are expressed as a percentage of the control value (without PAF for zero time) which was designated as $100 \%$. (c) Cells were incubated without (control) or with various concentrations of PAF for $10 \mathrm{~min}$. MAP kinase activation is expressed as a percentage of the control value which was designated as $100 \%$. Values are mean $\pm \operatorname{SE}(n=3)$. ${ }^{*} P<0.05,{ }^{* *} P<0.01$ versus control.

with $0.15 \mathrm{iu} \mathrm{hCG} \mathrm{ml}{ }^{-1}$ was obtained at $10 \mathrm{~min}$ after stimulation with $\mathrm{hCG}$, and then decreased gradually to the control value by $30 \mathrm{~min}$ (Fig. $4 \mathrm{a}, \mathrm{b}$ ).

The dose-response curve of MAP kinase activation with hCG was examined at concentrations from 0.015 to $1.5 \mathrm{iu} \mathrm{ml}^{-1}$. Maximum MAP kinase activation was obtained

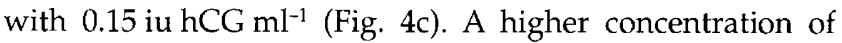
hCG (1.5 iu ml-1) inhibited MAP kinase activation (Fig. 4c).

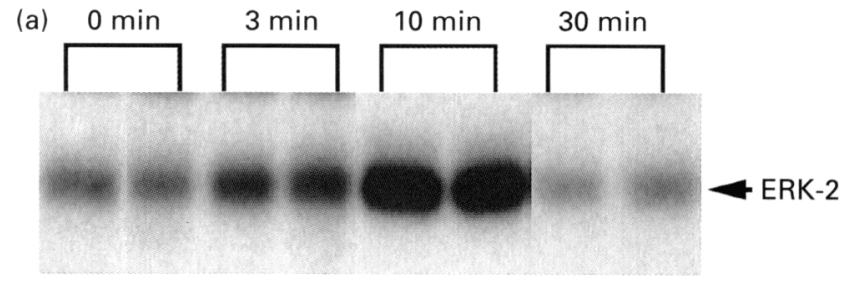

(b)

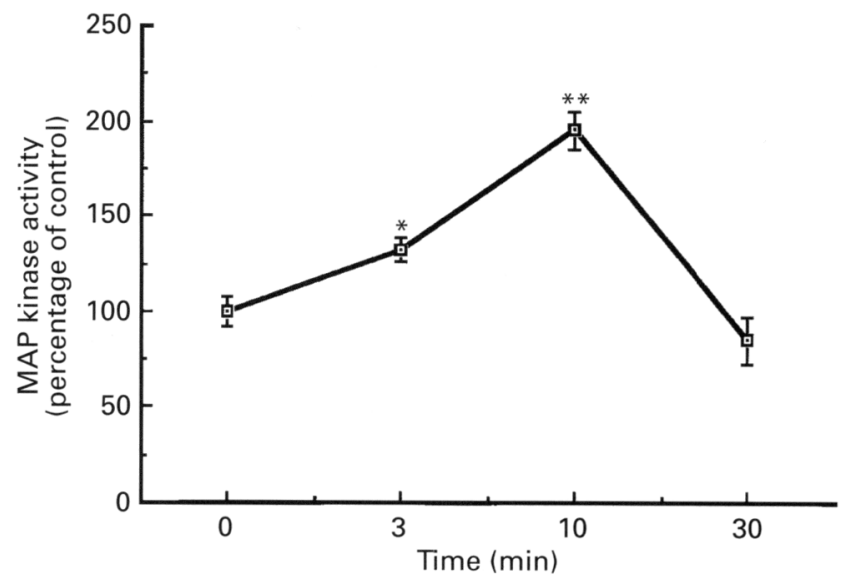

(c)

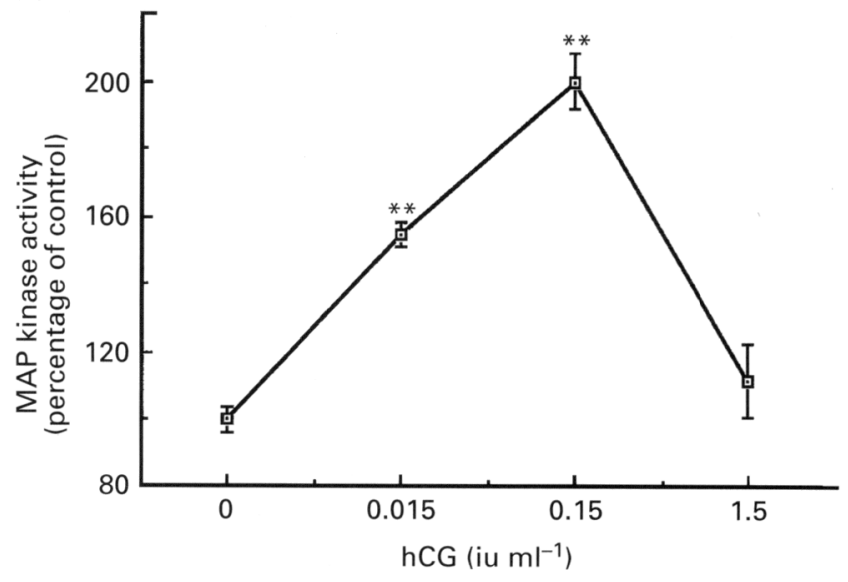

Fig. 4. Time course and concentration dependence of mitogenactivated protein kinase (MAP kinase) activation with hCG. (a) A representative autoradiogram of the time course of MAP kinase

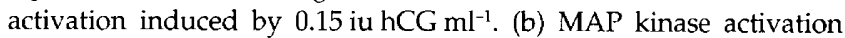
quantified by a Bio-imaging analyser. Values are expressed as a percentage of the control value which was designated as $100 \%$. (c) Cells were incubated without (control) or with various concentrations of $\mathrm{hCG}$ for $10 \mathrm{~min}$. MAP kinase activation is expressed as a percentage of the control value which was designated as $100 \%$. Values are means \pm SE $(n=3) .{ }^{*} P<0.05,{ }^{* *} P<0.01$ versus control.

\section{Effects of PD098059 and wortmannin on PAF-mediated $M A P$ kinase activation and COX-2 expression}

PD098059 is a selective inhibitor of the phosphorylation and kinase activity of MAP kinase kinase 1 (MEK-1) and MEK-2 (Alessi et al., 1995), the upstream kinases responsible for the phosphorylation of both tyrosine and threonine residues of ERK-1 and ERK-2. Pretreatment of the cells with 
(a)

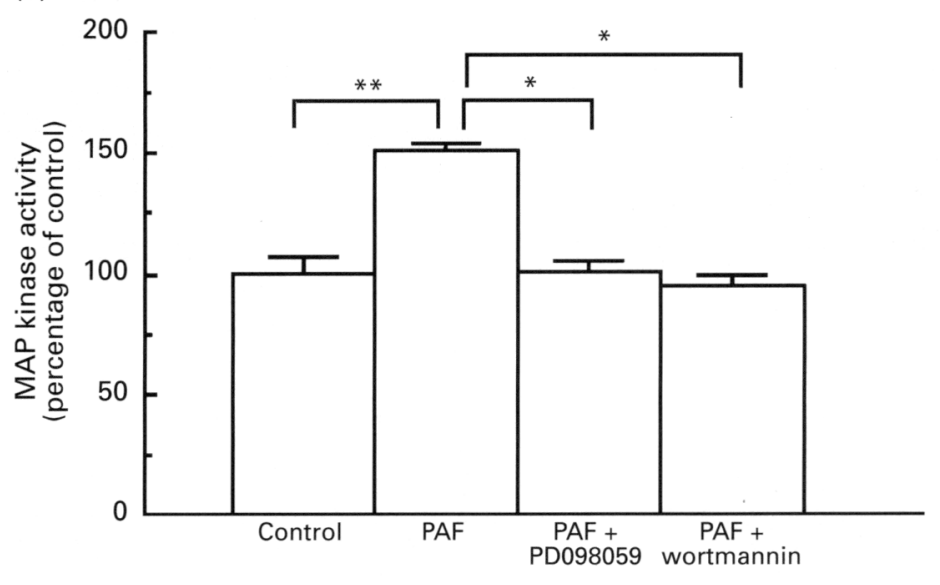

(b)

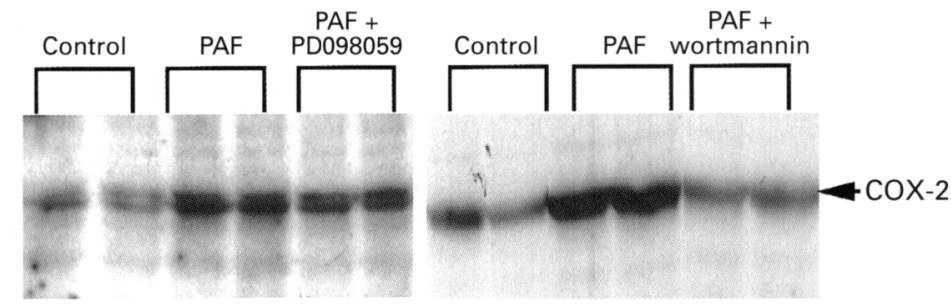

(c)

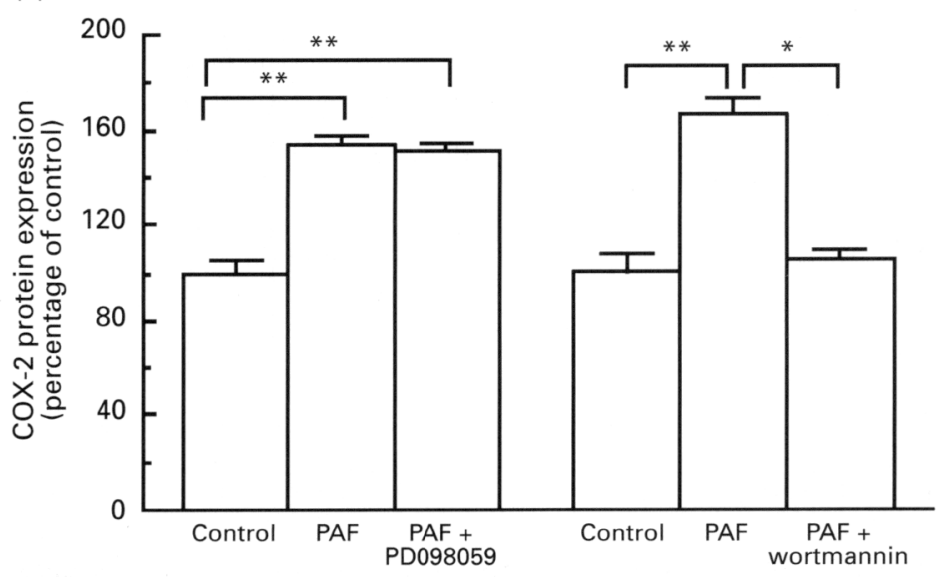

Fig. 5. Effects of PD098059 and wortmannin on platelet-activating factor (PAF)induced mitogen-activated protein kinase (MAP kinase) activation and COX-2 expression. (a) Effects of the inhibitors on PAF-induced MAP kinase activation. Cells were preincubated for $1 \mathrm{~h}$ in Krebs-Ringer Hepes (KRH) buffer and inhibitor (75 $\mu \mathrm{mol}$ PD098059 $\mathrm{l}^{-1}$ or $200 \mathrm{nmol}$ wortmannin $\mathrm{l}^{-1}$ ) was added for the last $30 \mathrm{~min}$ of preincubation. The cells were then incubated for $10 \mathrm{~min}$ without (control) or with $1 \mu \mathrm{mol} \mathrm{PAF}^{-1}$ in the presence of the inhibitor in KRH buffer. The data are expressed as a percentage of the control value which was designated as $100 \%$. Values are mean $\pm \mathrm{SE}$ $(n=3) .{ }^{*} P<0.05,{ }^{*} P<0.01$ versus control. (b) A representative autoradiogram showing the effects of the inhibitors on PAF-stimulated COX-2 expression. The cells were incubated for $12 \mathrm{~h}$ without (control) or with $1 \mu \mathrm{mol} \mathrm{PAF} \mathrm{l}^{-1}$ in the presence or absence of the inhibitors. (c) Effects of the inhibitors on PAF-induced COX-2 expression. The data are expressed as a percentage of the control value which was designated as $100 \%$. Values are mean \pm SE $(n=3) .{ }^{*} P<0.05,{ }^{* *} P<0.01$ versus control.

$75 \mu \mathrm{mol}$ PD098059 $\mathrm{l}^{-1}$ resulted in complete inhibition of MAP kinase activation (Fig. 5a), but had no effect on COX-2 expression (Fig. 5b,c). Wortmannin is a fungal metabolite that has been characterized as an inhibitor of phos-
phatidylinositol-3-OH kinase (PI3K) at nanomolar concentrations (Grammer and Blenis, 1997). Pretreatment of HEC-1B cells with $200 \mathrm{nmol}$ wortmannin $1^{-1}$ resulted in complete inhibition of PAF-mediated MAP kinase activation 
(a)

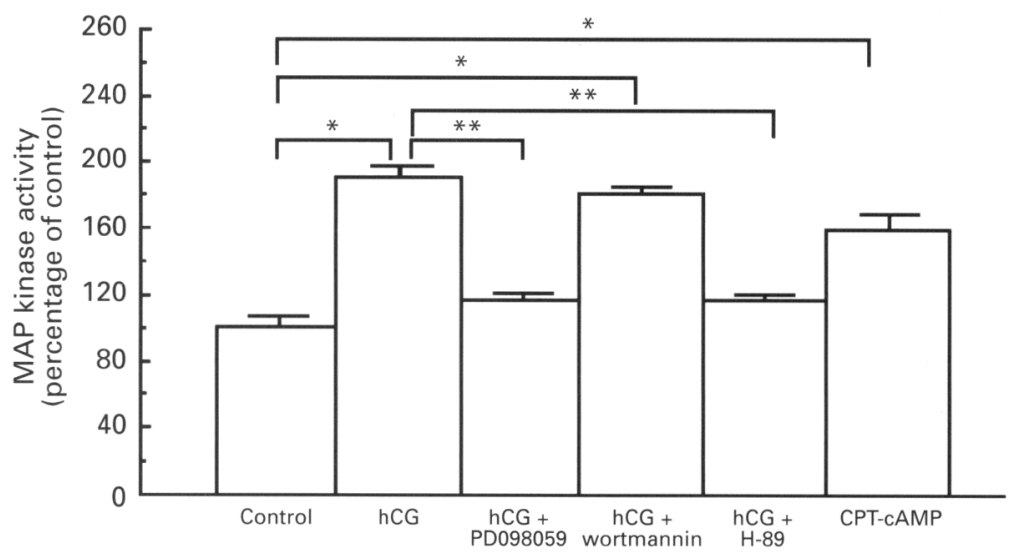

(b)
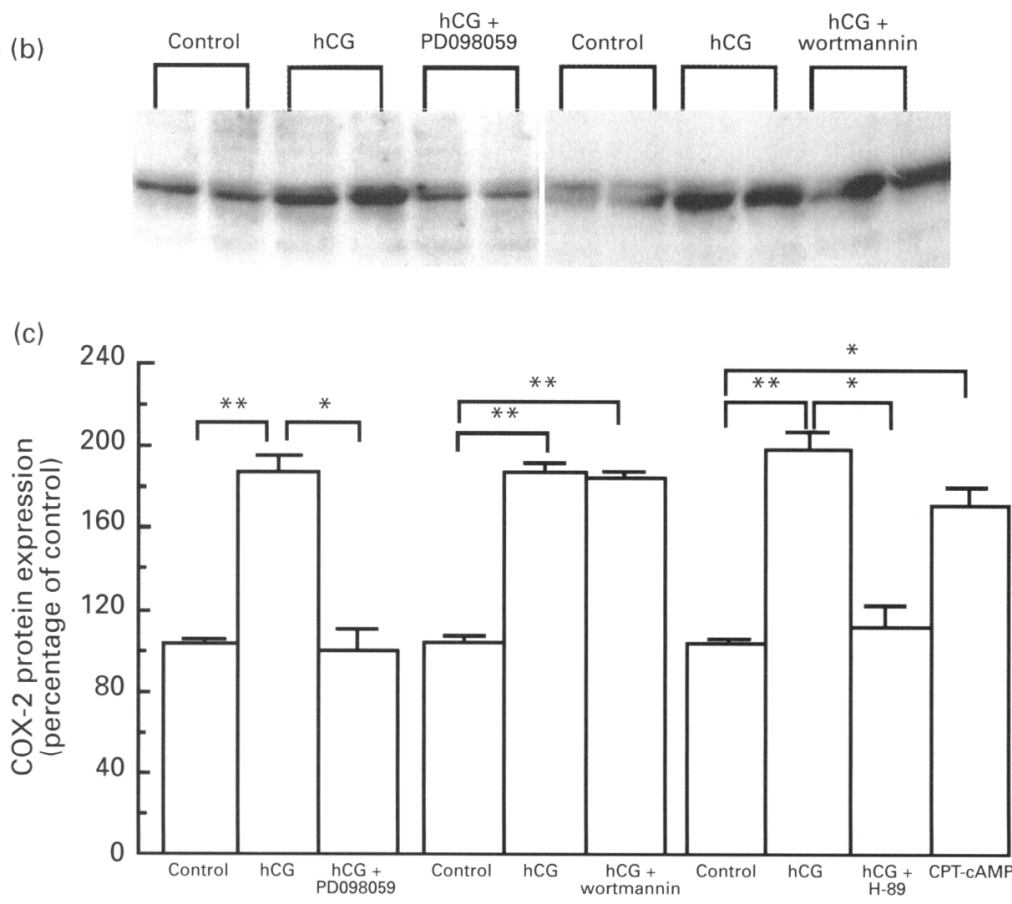

Fig. 6. Effects of PD098059, wortmannin and H-89 on hCG-induced mitogenactivated protein kinase (MAP kinase) activation and cyclooxygenase 2 (COX-2) expression and the effect of 8-(4-chlorophenylthio)-cAMP (CPT-cAMP). (a) Effects of the inhibitors on hCG-induced MAP kinase activation and effect of CPT-cAMP on MAP kinase activity. The cells were preincubated for $1 \mathrm{~h}$ in Krebs-Ringer Hepes buffer and inhibitor $\left(75 \mu \mathrm{mol}\right.$ PD098059 $\mathrm{l}^{-1}, 200 \mathrm{nmol}$ wortmannin $\mathrm{l}^{-1}$ or $10 \mu \mathrm{mol}$ $\left.\mathrm{H}-8 \mathrm{I}^{-1}\right)$ was added for the last $30 \mathrm{~min}$ of preincubation. The cells were then incubated for $10 \mathrm{~min}$ without (control) or with $0.15 \mathrm{iu} \mathrm{hCG} \mathrm{ml}{ }^{-1}$ in the presence of the inhibitor. In the case of CPT-cAMP, after preincubation in $\mathrm{KRH}$ buffer, cells were incubated with $1 \mathrm{mmol} \mathrm{CPT-CAMP}{ }^{-1}$ for $10 \mathrm{~min}$. The data are expressed as a percentage of the control value which was designated as $100 \%$. Values are mean \pm SE $(n=3) .{ }^{*} P<0.05,{ }^{* *} P<0.01$ versus control. (b) A representative autoradiogram showing the effects of PD098059 and wortmannin on hCG-stimulated COX-2 expression. The cells were incubated for $12 \mathrm{~h}$ without (control) or with $0.15 \mathrm{iu}$ hCG $\mathrm{ml}^{-1}$ in the presence or absence of inhibitor. (c) Statistical analyses of the data shown in (b) and the effects of H-89 and CPT-cAMP. The effect of H-89 on hCGinduced COX-2 expression was examined in the same way as for the other inhibitors. Cells were also incubated with $1 \mathrm{mmol} \mathrm{CPT-cAMP} \mathrm{l}^{-1}$ for $12 \mathrm{~h}$. The data are expressed as a percentage of the control value which was designated as $100 \%$. Values are mean $\pm \operatorname{SE}(n=3) .{ }^{*} P<0.05,{ }^{* *} P<0.01$ versus control. 
(Fig. 5a). Addition of $200 \mathrm{nmol}$ wortmannin $\mathrm{l}^{-1}$ and $1 \mu \mathrm{mol}$ PAF ${ }^{-1}$ inhibited both PAF-mediated MAP kinase activation and COX-2 expression (Fig. 5a,c). These results indicate that activation of MAP kinase and stimulation of COX-2 expression are regulated by at least two different pathways.

\section{Effects of PD098059, wortmannin and H-89 on hCG- mediated MAP kinase activation and COX-2 expression}

The effects of PD098059, wortmannin and H-89 on hCGinduced MAP kinase activation and COX-2 expression were examined (Fig. 6). H-89 is a specific inhibitor of protein kinase A (Chijiwa et al., 1990). hCG-induced MAP kinase activation was inhibited by addition of $75 \mu \mathrm{mol}$ PD098059 $\mathrm{l}^{-1}$ or $10 \mu \mathrm{mol} \mathrm{H}-89 \mathrm{l}^{-1}$, but was not inhibited with $200 \mathrm{nmol}$ wortmannin $\mathrm{l}^{-1}$. Similarly, both PD098059 and H-89 inhibited hCG-induced COX-2 expression, but wortmannin did not (Fig. 6b,c). These results indicate that MAP kinase activation is downstream of protein kinase A activity during stimulation with hCG, and that PAF (Fig. 5) and hCG (Fig. 6) have different effects on MAP kinase activation and COX-2 expression.

\section{Effect of CPT-CAMP on MAP kinase activation and COX-2 expression}

cAMP is thought to be the principal mediator of the actions of LH and hCG in gonadal cells (Segaloff and Ascoli, 1993). CPT-CAMP is a potent cAMP analogue and at a concentration of $1 \mathrm{mmol}^{-1}$ it increased the activation of MAP kinase (Fig. 6a). CPT-cAMP at a concentration of $1 \mathrm{mmol} \mathrm{l}^{-1}$ also increased expression of COX-2 (Fig. 6c).

\section{Discussion}

Endometrial cells are exposed to oestrogen and progesterone in a cyclical manner in vivo. In the present study, addition of both oestradiol and medroxyprogesterone acetate for 3-5 days increased MAP kinase activation and COX-2 expression induced by PAF and hCG in HEC-1B cells. Oestrogen and progesterone can induce modulation of RNA and protein synthesis within this time frame. Sato et al. (1996) reported that pretreatment with oestradiol or oestradiol plus progesterone for a period of $48 \mathrm{~h}$ induced accumulation of PAF receptor transcript in human endometrial epithelial cells in vitro, although how these steroids modulate the PAF and hCG response in HEC-1B cells remains to be elucidated.

PAF activates MAP kinase in Chinese hamster ovary cells expressing PAF receptor (Honda et al., 1994), as well as in blood cells (Ferby et al., 1994; Coffer et al., 1998). Interaction of PAF with the PAF receptor activates heterotrimeric G proteins (Hwang et al., 1986), which in turn activates phospholipase $C$ and increases intracellular calcium concentrations (Shukla, 1991). In Chinese hamster ovary cells, stimulation of the cloned PAF receptor activated MAP kinase through the activation of the upstream MEK in a G proteindependent manner (Honda et al., 1994). Stimulation of PAF receptors is capable of activating PI3K (Coffer et al., 1998) and MAP kinase activation with PAF is sensitive to wortmannin (Ferby et al., 1994), thus linking PI3K upstream to MAP kinase.

Segaloff and Ascoli (1993) suggested that the increase in intracellular cAMP elicited by binding of hCG to the LH and hCG receptor is the principal mediator of the actions of $\mathrm{LH}$ and hCG in gonadal cells. Cameron et al. (1996) reported for the first time that FSH and LH can activate MAP kinase in pig granulosa cells through a cAMP-dependent mechanism. However, there is insufficient evidence to explain the actual mechanism of gonadotrophin-stimulated MAP kinase activation.

In the present study, PD098059, a selective inhibitor of MEK-1 and MEK-2 (Alessi et al., 1995), completely inhibited PAF-induced MAP kinase activation. This result is consistent with similar observations made in HEC-1A cells after stimulation with PAF (Bonaccorsi et al., 1997). These findings indicate that MAP kinase activation with PAF is a result of p21 Ras-mediated signalling. PAF-induced activation of MAP kinase was also inhibited completely by wortmannin in the present study. However, other studies showed that PAF-induced MAP kinase activation was only partially inhibited by wortmannin (Ferby et al., 1994). Wortmannin at nanomolar concentrations is a specific inhibitor of PI3K (Grammer and Blenis, 1997). In a study using the HEC-1B cell line, Ahmed et al. (1995) reported that oestradiol upregulates PAF-induced phospholipase D activity. In addition, activation of phospholipase D was suppressed with PI3K inhibitors (Cissel et al., 1998). These observations imply that PI3K lies upstream to phospholipase D in HEC-1B cells.

In the present study, use of PD098059 resulted in complete inhibition of hCG-induced MAP kinase activation, providing evidence that MEK lies upstream of hCG-mediated MAP kinase activation. Unlike PAF, activation of MAP kinase by hCG was unchanged by wortmannin treatment. On the other hand, a cAMP-induced increase in MAP kinase activation and the ability of $\mathrm{H}-89$ to inhibit hCG-induced MAP kinase activity supports the view that CAMP lies upstream of the hCG-induced MAP kinase activation pathway.

Many studies have focused on regulation of COX-2 by MAP kinase. Use of promoter deletion and site-directed mutagenesis of COX-2 luciferase chimeric reporter genes showed that MAP kinase is partially involved in v-src- (Xie and Herschman, 1995), serum-, and PDGF-induced COX-2 induction in NIH 3T3 cells (Xie and Herschman, 1996). PD098059 also blocked stimulation of lysophosphatidic acidmediated COX-2 expression in rat mesangial cells (Reiser $e t$ al., 1998) and lipopolysaccharide-induced COX-2 expression in a murine macrophage cell line (Hwang et al., 1997). Contrary to these reports, PAF-induced COX-2 expression was not inhibited by addition of PD098059 in the present study. However, wortmannin was effective at blocking the PAF-induced COX-2 expression. In view of the low concentration of wortmannin used $\left(200 \mathrm{nmol} \mathrm{l}^{-1}\right)$, its effects would be expected to be exerted through specific inhibition of PI3K. PI3K has been implicated in the activation of jun Nterminal kinase (JNK) (Klippel et al., 1996), nuclear factor kappa B (NF kappa B), and activated protein 1 (AP-1) (Reddy 
et al., 1997), all of which are associated with stimulation of COX-2 expression. Furthermore, protein kinase B (PKB/c-Akt) has been identified as a downstream target of PI3K (Burgering and Coffer, 1995). Pedersen et al. (1997) reported that wortmannin inhibited protein synthesis by affecting translation. It is concluded that PAF-induced expression of COX-2 is probably mediated through the PI3K signalling pathway, although the reactions downstream to the PI3K pathway remain to be determined.

Consistent with other studies, in the present study, PD098059 inhibited hCG-mediated COX-2 expression. This implicates a role for MAP kinase in hCG-mediated COX-2 expression. In addition, CPT-cAMP stimulated COX-2 expression directly and hCG-induced $\mathrm{COX}-2$ expression was inhibited by H-89. H-89 also inhibited hCG-induced MAP kinase activation, so it appears that MAP kinase is the ultimate effector in this kinase cascade. Borsch-Haubold et al. (1998) reported that the activity of COX-1 and COX-2 was inhibited by PD098059 at micromolar concentrations. Since, in the present study, the activity of COX-2 was not determined but the expression of COX-2 was measured by inhibition of MAP kinase, it is considered that the use of PD098059 did not influence the results.

Studies in knockout mice showed that COX-2 is a critical protein for implantation and decidualization (Lim et al., 1997). Because PAF is involved in implantation and hCG is involved in decidualization, and PAF (Alecozay et al., 1989) and hCG are present in the luteal phase endometrium, the regulation of PAF- and hCG-induced COX-2 expression may be important in these events.

This work was supported in part by Grants-in-Aid for Scientific Research and for Scientific Research on priority from the Ministry of Education, Science, Sports and Culture, Japan, and by a Research Grant from the Human Frontier Science Program (E. Miyamoto and K. Fukunaga)

\section{References}

Ahmed A, Sage SO, Plevin R, Shoaibi MA, Sharkey AM and Smith SK (1994) Functional platelet-activating factor receptors linked to inositol lipid hydrolysis, calcium mobilization and tyrosine kinase activity in the human endometrial HEC-1B cell line Journal of Reproduction and Fertility $101459-466$

Ahmed A, Shoaibi MA, Plevin R and Smith SK (1995) Oestradiol-17 beta modulates PAF-evoked phospholipase $\mathrm{D}$ activity but not inositide-lipid hydrolysis in human endometrial cell line, HEC-1B Cellular Signalling 7 403-409

Alecozay AA, Casselen BG, Riehl RM, Deleon FD, Harper MJK, Silvia M, Nouchi TA and Hanahan DJ (1989) Platelet-activating factor in human luteal phase endometrium Biology of Reproduction 41 578-586

Alessi DR, Cuenda A, Cohen P, Dudley DT and Saltiel AR (1995) PD 098059 is a specific inhibitor of the activation of mitogen-activated protein kinase in vitro and in vivo. Journal of Biological Chemistry 270 $27489-27494$

Battye KM, O'Neill C and Evans G (1992) Evidence that platelet activating factor suppresses uterine oxytocin-induced 13,14 dihydro-15 keto-prostaglandin F2alpha release and phosphatidylinositol hydrolysis in the ewe Biology of Reproduction $47213-219$

Bonaccorsi L, Luconi M, Maggi M, Muratori M, Forti G, Serio M and Baldi $E$ (1997) Protein tyrosine kinase, mitogen-activated protein kinase and protein kinase $C$ are involved in the mitogenic signaling of platelet-activating factor (PAF) in HEC-1A cells Biochimica et Biophysica Acta 1355 155-166

Borsch-Haubold A, Pasquet S and Watson S (1998) Direct inhibition of cyclooxygenase-1 and -2 by the kinase inhibitors SB 203580 and PD 98059 journal of Biological Chemistry $27328766-28772$
Bradford MM (1976) A rapid and sensitive method for the quantitation of microgram quantities of protein utilizing the principle of protein-dye binding Analytical Biochemistry 72 248-254

Burgering BM and Coffer PJ (1995) Protein kinase B (c-Akt) in phosphatidylinositol-3-OH kinase signal transduction Nature 376 599-602

Cameron MR, Foster JS, Bukovsky A and Wimalasena J (1996) Activation of mitogen-activated protein kinases by gonadotropins and cyclic adenosine 5'-monophosphates in porcine granulosa cells Biology of Reproduction $\mathbf{5 5}$ 111-119

Chakraborty I, Das SK, Wanj J and Dey SK (1996) Developmental expression of the cyclooxygenase- 1 and cyclooxygenase- 2 genes in the periimplantation mouse uterus and their differential regulation by the blastocyst and ovarian steroids Journal of Molecular Endocrinology 16 107-122

Chijiwa T, Mishima A, Hagiwara M, Sano M, Hayashi K, Inoue T, Naito K, Toshioka T and Hidaka H (1990) Inhibition of forskolin-induced neurite outgrowth and protein phosphorylation by a newly synthesized selective inhibitor of cyclic AMP-dependent protein kinase, $N$-[2-( $p$-bromocinnamylamino)ethyl]-5-isoquinolinesulfonamide (H-89), of PC12D pheochromocytoma cells Journal of Biological Chemistry 265 5267-5272

Cissel DS, Fraundorfer PF and Beaven MA (1998) Thapsigargin-induced secretion is dependent on activation of a cholera toxin-sensitive and phosphatidylinositol-3-kinase-regulated phospholipase $D$ in a mast cell line Journal of Pharmacology and Experimental Therapeutics 285 110-118

Coffer PJ, Schweizer RC, Dubois GR, Maikoe T, Lammers JW and Koenderman L (1998) Analysis of signal transduction pathways in human eosinophils activated by chemoattractants and the T-heiper 2-derived cytokines interleukin-4 and interleukin-5 Blood 91 2547-2557

Collier M, O'Neill C, Ammit AJ and Saunders DM (1988) Biochemical and pharmacological characterization of human embryo-derived plateletactivating factor Human Reproduction 3993-998

Deibler GE, Martenson RE and Kies MW (1972) Large scale preparation of myelin basic protein from central nervous tissue of several mammalian species Preparative Biochemistry 2 139-165

Ferby IM, Waga I, Sakanaka C, Kume K and Shimizu T (1994) Wortmannin inhibits mitogen-activated protein kinase activation induced by plateletactivating factor in guinea pig neutrophils Journal of Biological Chemistry 269 30 485-30488

Grammer TC and Blenis J (1997) Evidence for MEK-independent pathways regulating the prolonged activation of the ERK-MAP kinases Oncogene 14 1635-1640

Han SW, Lei ZM, Sanfilippo JS and Rao ChV (1995a) Human chorionic gonadotropin as a new regulator of human endometrial stromal cells differentiation into decidua $77 t h$ Annual Meeting of the Endocrine Society, Washington DC (Abstract P 2-84)

Han SW, Lei ZM and Rao ChV (1995b) Upregulation of cyclooxygenase-2 gene expression by chorionic gonadotropin during the differentiation of human endometrial stromal cells into decidua Endocrinology 137 1791-1797

Honda Z, Takano T, Gotoh Y, Nishida E, Ito K and Shimizu T (1994) Transfected platelet-activating factor receptor activates mitogen-activated protein (MAP) kinase and MAP kinase kinase in Chinese hamster ovary cells Journal of Biological Chemistry $2692307-2315$

Hwang D, Jang BC, Yu G and Boudreau M (1997) Expression of mitogeninducible cyclooxygenase induced by lipopolysaccharide: mediation through both mitogen-activated protein kinase and NF-kappaB signaling pathways in macrophages Biochemical Pharmacology 54 87-96

Hwang SB, Lam MH and Pong SS (1986) lonic and GTP regulation of binding of platelet-activating factor to receptors and platelet-activating factorinduced activation of GTPase in rabbit platelet membranes journal of Biological Chemistry 261 532-537

Kelly RW (1994) Pregnancy maintenance and parturition: the role of prostaglandin in manipulating the immune and inflammatory response Endocrine Reviews 15 684-705

Kennedy TG (1985) Evidence for the involvement of prostaglandins throughout the decidual cell reaction in the rat Biology of Reproduction 33 140-146

Klippel A, Reinhard C, Kavanaugh WM, Apell G, Escobedo MA and Williams LT (1996) Membrane localization of phosphatidylinositol 3-kinase is sufficient to activate multiple signal-transducing kinase pathways Molecular and Cellular Biology 16 4117-4127

Kurino M, Fukunaga K, Ushio $Y$ and Miyamoto E (1995) Activation of mitogen-activated protein kinase in cultured rat hippocampal neurons by stimulation of glutamate receptors Journal of Neurochemistry 65 1282-1289

Laemmli UK (1970) Cleavage of structural proteins during the assembly of the head of bacteriophage T4 Nature $227680-685$ 
Lim H, Paria BC, Das SK and Dinchuk JE (1997) Multiple female reproductive failures in cyclooxygenase 2-deficient mice Cell 91 197-208

McRae AC and Heap RB (1988) Uterine vascular permeability, blood flow and extracellular fluid space during implantation in rats Journal of Reproduction and Fertility 82 617-625

Norman SJ and Poyser NL (1992) The effects of platelet activating factor on the output of prostaglandins from the guinea pig uterus Prostaglandins Leukotrienes and Essential Fatty Acids 47 285-289

O'Neill C, Gidley-Baird AA, Pike IL and Saunders FM (1987) Use of a bioassay for embryo-derived platelet-activating factor as means of assessing quality and pregnancy potential of human embryos Feritlity and Sterility 47 969-975

Oyama S and Izutsu T (1992) Cell cycle analysis of endometrial cancer cells in vitro treated with growth factor and steroid hormone Human Cell 5363-371

Pedersen S, Celis JE, Nielsen J, Christiansen J and Nielsen FC (1997) Distinct repression of translation by wortmannin and rapamycin European Journal of Biochemistry $247449-456$

Reddy SA, Huang JH and Liao WS (1997) Phosphatidylinositol 3-kinase in interleukin 1 signaling. Physical interaction with the interleukin 1 receptor and requirement in NFkappaB and AP-1 activation Journal of Biological Chemistry 27229 167-29173

Reiser CO, Lanz T, Hofmann F, Hofer G, Rupprecht HD and GoppeltStruebe M (1998) Lysophosphatidic acid-mediated signal-transduction pathways involved in the induction of the early-response genes prostaglandin $\mathrm{G} / \mathrm{H}$ synthase-2 and Egr-1: a critical role for the mitogenactivated protein kinase p38 and for Rho proteins Biochemcal Journal 330 $1107-1114$
Reshef E, Lei ZM, Rao ChV, Pridham DD, Chegini N and Luborsky JL (1990) The presence of gonadotropin receptors in non-pregnant human uterus, human placenta, fetal membranes and decidua Journal of Clinical Endocrinology and Metabolism $70421-429$

Sato S, Kume K, Takan T, Mutoh H, Taketani Y and Shimizu T (1996) Upregulation of the intracellular $\mathrm{Ca}^{2+}$ signaling and mRNA expression of platelet-activating factor receptor by estradiol in human uterine endometrial cells Advances in Experimental Medicine and Biology 416 95-100

Satyaswaroop PG, Fleming H, Bressler RS and Gurpide E (1978) Human endometrial cancer cell cultures for hormonal studies Cancer Research 38 $4367-4375$

Segaloff DL and Ascoli M (1993) The lutropin/choriogonadotropin receptor ... 4 years later Endocrine Reviews 14 324-347

Shukla SD (1991) Inositol phospholipid turnover in PAF transmembrane signalling Lipids 26 1028-1033

Smith WL and Dewitt DL (1996) Prostaglandin endoperoxide H synthases-1 and -2 Advances in Immunology 62 167-215

Xie $W$ and Herschman HR (1995) v-src induces prostaglandin synthase 2 gene expression by activation of the c-Jun $\mathrm{N}$-terminal kinase and the c-Jun transcription factor Journal of Biological Chemistry 270 $27622-27628$

Xie W and Herschman HR (1996) Transcriptional regulation of prostaglandin synthase 2 gene expression by platelet-derived growth factor and serum Journal of Biological Chemistry 27131 742-31 748

Yang ZM, Das SK, Wang J, Sugimoto Y, Ichikawa A and Dey SK (1997) Potential sites of prostaglandin actions in the periimplantation mouse uterus: differential expression and regulation of prostaglandin receptor genes Biology of Reproduction 56 368-379 